\title{
Alkaline Sodium Hypochlorite Irrigant and Its Chemical Interactions
}

\author{
Patricia P. Wright * (1), Bill Kahler and Laurence J. Walsh \\ The University of Queensland School of Dentistry, Brisbane 4006, Australia; wyattkahler@bigpond.com (B.K.); \\ l.walsh@uq.edu.au (L.J.W.) \\ * Correspondence: p.wright1@uq.edu.au; Tel.: +61-733-658-056
}

Received: 5 September 2017; Accepted: 24 September 2017; Published: 29 September 2017

\begin{abstract}
Endodontic irrigating solutions may interact chemically with one another. This is important, because even when solutions are not admixed, they will come into contact with one another during an alternating irrigation technique, forming unwanted by-products, which may be toxic or irritant. Mixing or alternating irrigants can also reduce their ability to clean and disinfect the root canal system of teeth by changing their chemical structure with subsequent loss of the active agent, or by inducing precipitate formation in the root canal system. Precipitates occlude dental tubules, resulting in less penetration of antimicrobials and a loss of disinfection efficacy. Sodium hypochlorite is not only a very reactive oxidizing agent, but is also the most commonly used endodontic irrigant. As such, many interactions occurring between it and other irrigants, chelators and other antimicrobials, may occur. Of particular interest is the interaction between sodium hypochlorite and the chelators EDTA, citric acid and etidronate and between sodium hypochlorite and the antimicrobials chlorhexidine, alexidine, MTAD and octenisept.
\end{abstract}

Keywords: endodontic irrigant interactions; clinical implications; sodium hypochlorite; EDTA; citric acid; etidronate; chlorhexidine; MTAD; alexidine; octenisept

\section{Introduction}

The use of sodium hypochlorite $(\mathrm{NaOCl})$ dates back over 100 years, when Dakin, recognizing its great reactivity and its ability to chemically digest organic matter, reported the use of an $0.5 \%$ solution for wound disinfection [1]. Its application to root canal therapy is credited to Alfred Walker in 1936 [2]. The unique ability of $\mathrm{NaOCl}$ to both dissolve organic tissue and to disinfect has made it the irrigant of choice in contemporary endodontics [3,4]. NaOCl will not, however, remove smear layer, so it is used in conjunction with a chelating agent to remove inorganic components [5]. Ethylenediaminetetraacetic acid (EDTA) is utilized mostly for this purpose [6]. However, chelators such as citric acid or other organic acids have been used [5]. More recently, the bisphosphonate etidronate has been assessed for mixing with $\mathrm{NaOCl}[7]$.

When tested on mature biofilms of clinical isolates of endodontic infection, $\mathrm{NaOCl}$ has superior antimicrobial activity compared to several other irrigants; however, it neither totally eradicates biofilm volume, nor achieves complete killing of bacteria [8]. Strategies to augment its use for disinfection include combination with other antimicrobial agents [9] or chelators [7] in the same solution, the use of a rinse sequence employing $\mathrm{NaOCl}$ with EDTA or other chelator or antimicrobial agent [10], and flushing the root canal with a solution possessing additional disinfection ability following irrigation with $\mathrm{NaOCl}[11]$.

$\mathrm{NaOCl}$ solutions used in endodontic irrigation range in concentration from $0.5-6 \%$ [6]. The $\mathrm{pH}$ and hydroxide ion $\left(\mathrm{OH}^{-}\right)$concentration vary significantly according to brand, and can range between 10.9 to 12.0 for $\mathrm{pH}$, and from $0.03-1.1 \%$ for $\mathrm{OH}^{-}$concentration [12]. There are products available 
with more $\mathrm{OH}^{-}$that have a higher $\mathrm{pH}$. It is also worth noting that endodontics is often performed with commercial bleaches used for general cleaning, such as Chlorox, which may result in the use of inappropriately high levels of $\mathrm{NaOCl}$ [13]. The reactions of $\mathrm{NaOCl}$ with other irrigants, as well as its clinical properties are better appreciated by understanding the various chemical species present at different $\mathrm{pH}$ levels. At $\mathrm{pH}$ values of 9 and above, the hypochlorite ion $\left(\mathrm{OCl}^{-}\right)$predominates. At neutral $\mathrm{pH}$, hypochlorous acid $(\mathrm{HOCl})$ is mostly present, while below $\mathrm{pH} 4$, chlorine gas starts to form [14]. The antibacterial ability is maximized at $\mathrm{pH}$ conditions where $\mathrm{HOCl}$ predominates. In contrast, at higher $\mathrm{pH}$ levels where $\mathrm{OCl}^{-}$is present, tissue dissolution is maximized [15]. The $\mathrm{pH}$ of $\mathrm{NaOCl}$ solutions can be lowered by its reaction with other irrigants [16] or when it comes into contact with dentine [17], and thus, there is potential for hypochlorite to be present in multiple forms.

$\mathrm{NaOCl}$ is a strong oxidizing agent with a reduction potential of $1.6 E^{\circ} / V$ [18]. The oxidation state of the chlorine atom in $\mathrm{NaOCl}$ is +1 . Chlorine then acts as an electrophile, reacting with electron sources such as aromatic rings, doubly bonded carbon atoms, amino and sulphydryl groups [14]. The reaction with amino groups results in chloramine formation [14]. Additionally, $\mathrm{OH}^{-}$is a nucleophile, and can drive chemical reactions [19].

\section{Reactions of Sodium Hypochlorite with Chelating Agents}

\subsection{Reactions of Sodium Hypochlorite with Ethylenediaminetetraacetic Acid}

\subsubsection{Chemistry}

EDTA is used commonly at concentrations of $15 \%$ or $17 \%$. Aqueous solutions are prepared by dissolving the di- or trisodium salts, resulting in a neutral to slightly alkaline $\mathrm{pH}[3,20]$. At this $\mathrm{pH}$, the reaction between $\mathrm{NaOCl}$ and EDTA is exothermic [21], and mixing $\mathrm{NaOCl}$ with EDTA results in a rapid and dramatic decrease of free available chlorine [7,21,22]. Gas formation has been observed from this combination [23], and low level chlorine gas emissions have been measured [20]. This interaction has been attributed to an acid/base neutralization reaction between $\mathrm{NaOCl}$ and EDTA, with the formation of $\mathrm{HOCl}$, which then subsequently decomposes, releasing chlorine and oxygen, according to Equation (1) below [20].

$$
4 \mathrm{HOCl} \rightleftharpoons 2 \mathrm{Cl}_{2}+\mathrm{O}_{2}+2 \mathrm{H}_{2} \mathrm{O}
$$

The remaining free available chlorine in a $1: 1$ mixture of $1 \% \mathrm{NaOCl}$ and $17 \%$ EDTA at $1 \mathrm{~min}$ is $10 \%$, but this declines to $\% \%$ at one hour after mixing [7]. The decomposition of $\mathrm{HOCl}$ occurs when the $\mathrm{pH}$ is less than 4 . This is much lower than the $\mathrm{pH}$ of the standard EDTA/ $\mathrm{NaOCl}$ combination, which is 7.9-8.0 up to one hour from mixing [16]. However, the presence of chloride ions can shift the equilibrium, according to Le Chatelier's principle, to favor chlorine formation, as in Equation (2). Some formulations of $\mathrm{NaOCl}$ are known to have high sodium chloride levels [21], thus encouraging this effect [23].

$$
\mathrm{HOCl}+\mathrm{Cl}^{-}+\mathrm{H}^{+} \rightleftharpoons \mathrm{Cl}_{2}+\mathrm{H}_{2} \mathrm{O}
$$

In the above reactions, the EDTA molecule is left intact [20]. However, as nuclear magnetic resonance ${ }^{1} \mathrm{H}$ spectroscopy $\left({ }^{1} \mathrm{H}\right.$ NMR) studies have identified unspecified and slowly formed EDTA breakdown products [24], these are not the only reaction mechanisms in operation. The formation of chloramines has been suggested [21], which would occur via chlorine electrophilic attack on EDTA amino groups.

Recently, more alkaline solutions have been achieved by mixing the tetrasodium salt of EDTA $\left(\mathrm{Na}_{4}\right.$ EDTA) with $\mathrm{NaOCl}$. This combination results in the longer maintenance of both free available chlorine and desirable $\mathrm{pH}$ conditions [16], although concentrations of both EDTA and $\mathrm{NaOCl}$ need to be reduced to obtain this result [25]. The $\mathrm{pH}$ of a 1:1 mixture of $5 \% \mathrm{NaOCl}$ and $10 \% \mathrm{Na}_{4}$ EDTA falls from 11.9 at $10 \mathrm{~min}$ after mixing to 9.0 at one hour after mixing, during which period the remaining free available chlorine declines from $90 \%$ to $62 \%$ [16]. 


\subsubsection{Clinical Implications}

For mixtures of EDTA and $\mathrm{NaOCl}$ that have a low $\mathrm{pH}$, the loss of free available chlorine significantly reduces the ability of $\mathrm{NaOCl}$ to dissolve organic tissue [22,26]. Thus, these irrigants should neither be mixed, nor come into contact with one another. The chelating ability of EDTA [7] and the disinfecting capacity of $\mathrm{NaOCl}$ are, however, maintained [7,22].

This is in contrast to more alkaline mixtures using $\mathrm{Na}_{4}$ EDTA, which, when combined with $\mathrm{NaOCl}$, maintain some ability to dissolve organic matter. When $5 \% \mathrm{NaOCl}$ is mixed $1: 1$ with $10 \% \mathrm{Na}_{4}$ EDTA, resulting in $2.5 \% \mathrm{NaOCl}$ and $5 \% \mathrm{Na}_{4}$ EDTA, tissue dissolution at $15 \mathrm{~min}$ is comparable to that of $2.5 \% \mathrm{NaOCl}$, resulting in a short therapeutic window [16].

Also of clinical relevance, a case report attributing a subcutaneous emphysema to gas formation, resulting from the interaction of RC-Prep with $\mathrm{NaOCl}$, has been reported [27]. RC-Prep contains both EDTA and urea peroxide and reactions of these components with $\mathrm{NaOCl}$ is possible.

\subsection{Reactions of Sodium Hypochlorite and Citric Acid}

\subsubsection{Chemistry}

Citric acid is a tricarboxylic acid and a tridentate ligand that will chelate $\mathrm{Ca}^{2+}$. When $\mathrm{NaOCl}$ and citric acid are mixed, the resulting $\mathrm{pH}$ is considerably lower than the mixture of $\mathrm{NaOCl}$ and EDTA. A 1:1 mixture of 2.5\% $\mathrm{NaOCl}$ and $10 \%$ citric has a $\mathrm{pH}$ of 3.1 [28]. Low $\mathrm{pH}$ levels favors chlorine formation, and production of this gas has been measured in a 1:1 mixture of $5.25 \% \mathrm{NaOCl}$ and $50 \%$ citric acid at 7 times the level of that of in a 1:1 mixture of $5.25 \% \mathrm{NaOCl}$ and $15 \%$ EDTA [20]. However, bubble formation in mixtures of $\mathrm{NaOCl}$ and citric acid has been observed at the much lower citric acid concentration of $10 \%$ when combined with $5.25 \%, 2.5 \%$ and $1 \%$ solutions of $\mathrm{NaOCl}$ [23]. Free available chlorine is depleted rapidly from combinations of $\mathrm{NaOCl}$ and citric acid $[7,28]$, with a 1:1 mixture of $1 \% \mathrm{NaOCl}: 10 \%$ citric acid losing all of its free available chlorine after only one minute [7].

\subsubsection{Clinical Implications}

As can be expected from the observations of chlorine formation and loss of free available chlorine, mixtures of $\mathrm{NaOCl}$ and citric acid lose their ability to dissolve organic tissue [10]. Citric acid and $\mathrm{NaOCl}$ should then not be present together during root canal therapy, either admixed or used sequentially. However, citric acid in combination with $\mathrm{NaOCl}$ does maintain both its chelation [7] and antimicrobial action $[7,28]$.

\subsection{Reactions of Sodium Hypochlorite with Etidronate}

Because of the above interactions of $\mathrm{NaOCl}$ with EDTA and citric acid, alternative chelators to use in mixtures with $\mathrm{NaOCl}$ have been sought. Etidronate has emerged as one such possible chelator, and has been tested in these mixtures at concentrations of $9 \%$ and $18 \%[25,29]$.

\subsubsection{Chemistry}

Etidronate is a chelator of calcium ions [7]. Little has been documented of the chemical reaction between $\mathrm{NaOCl}$ and etidronate; however, it is thought to break down to acetic acid [25]. The $\mathrm{pH}$ range of a solution containing $5 \% \mathrm{NaOCl}$ and $18 \%$ etidronate up to one hour after mixing is 8.6-8.7 [25]. The $\mathrm{pH}$ range is, however, dependent on the $\mathrm{NaOCl}$ concentration, with lower concentrations having a higher $\mathrm{pH}$ [25]. It can thus be expected that over a 60-min period, as a basic solution is maintained, $\mathrm{NaOCl}$ is predominantly in the $\mathrm{OCl}^{-}$form. Free available chlorine is lost at a considerably slower rate when $\mathrm{NaOCl}$ is combined with etidronate compared to when it is mixed with di- or trisodium EDTA or citric acid. A 1:1 mixture of 1\% NaOCl: $9 \%$ etidronate maintains all of its free available chlorine at $1 \mathrm{~min}$, and this declines to $80 \%$ at $60 \mathrm{~min}$ and to $20 \%$ after $24 \mathrm{~h} \mathrm{[7].} \mathrm{This} \mathrm{mixture} \mathrm{loses} \mathrm{less} \mathrm{free} \mathrm{available}$ chlorine compared to the mixture of $\mathrm{NaOCl}$ with $\mathrm{Na}_{4}$ EDTA [25]. 


\subsubsection{Clinical Implications}

Due to the maintenance of higher $\mathrm{pH}$ and free available chlorine levels in the mixture of $\mathrm{NaOCl}$ with etidronate, a therapeutic window of one hour exists, with acceptable levels of organic tissue dissolution being recorded within this timeframe [29].

Comparing the use of an etidronate/ $\mathrm{NaOCl}$ combination to a final rinse of neutral $\mathrm{pH}$ EDTA, the calcium chelation of the former is half to two thirds less [7,30], although it appears sufficient to remove smear layer [30]. The ability of $\mathrm{NaOCl}$ to disinfect the root canal is maintained in the combination [31].

\section{Reactions of $\mathrm{NaOCl}$ with Antimicrobial Agents or Antimicrobial/Chelator Mixtures}

\subsection{Reactions of Sodium Hypochlorite with Chlorhexidine}

\subsubsection{Chemistry}

Chlorhexidine (CHX) is a cationic bisbiguanide with broad spectrum antimicrobial actions, particularly against Gram-positive bacteria [32]. The two biguanide units are linked by an aliphatic chain, and both are terminated by 4-chlorophenyl side groups [33]. When solutions of $\mathrm{CHX}$ and $\mathrm{NaOCl}$ come into contact, an orange-brown precipitate is formed [34,35]. There has been considerable debate about the composition of the precipitate, with different analytical techniques showing contradictory results. The presence of parachloroanaline (PCA) was reported in studies based on time-of-flight ion mass spectroscopy [34,36], gas chromatography/mass spectroscopy (GC/MS) [37] or combined ${ }^{1} \mathrm{H}$ NMR/chemical analysis [35], whilst in other studies using ${ }^{1} \mathrm{H}$ NMR [19,38], no PCA was detected. Finally, a decisive study employing a variety of techniques including high performance, thin layer and gas chromatography techniques, ${ }^{1} \mathrm{H}$ NMR, infrared spectroscopy and GC/MS showed that PCA was not present in the precipitate [39]. Chlorophenylurea has been proposed as one of the components of the precipitate [19].

\subsubsection{Clinical Implications}

$\mathrm{CHX}$ has been suggested for use in endodontic irrigation as a final rinse following $\mathrm{NaOCl}$ irrigation to achieve more bacterial killing than $\mathrm{NaOCl}$ alone [6]. This is particularly the case for retreatments when Enterococcus faecalis may be present [40]. The precipitation products, although not positively identified, are worrying because of their probable similarity to the known toxin, chloroguanidine [19]. Additionally, these precipitates have been found within dentinal tubules [36] and in a layer on the main canal where they occlude the canal orifice [41,42], reducing dentine permeability and lowering the efficacy of endodontic irrigants [43]. Lastly, any colored material in the root canal has the potential to stain dentine.

\subsection{Reactions of Sodium Hypochlorite with Alexidine}

\subsubsection{Chemistry}

Alexidine (ALX) is a bisbiguanide that is similar in structure to CHX, except that the side chains consist of 2-ethylhexyl groups instead of the chlorophenyl groups of CHX [33]. In its reaction with $\mathrm{NaOCl}$, having no aromatic components, the question of PCA by-product formation is non-existent, and this has been shown to be the case [44]. When $4 \% \mathrm{NaOCl}$ is added to ALX, a pale-yellow cloudy reaction product is observed with ALX concentrations of $1 \%, 0.5 \%, 0.25 \%$, fading to clear for a $0.125 \%$ solution [44].

\subsubsection{Clinical Implications}

The yellow reaction by-product has not been identified, and thus its toxicity is yet to be determined. Compared to the blocked dentinal tubules observed from the $\mathrm{CHX} / \mathrm{NaOCl}$ combination, scanning 
electron microscopy (SEM) shows root canal irrigation with an $\mathrm{ALX} / \mathrm{NaOCl}$ mixture results in largely patent dentinal tubules, although it is unclear how this situation compares to alternating $\mathrm{NaOCl}$ and EDTA solutions [44].

\subsection{Reactions of Sodium Hypochlorite with MTAD}

\subsubsection{Chemistry}

MTAD is an endodontic irrigant containing 3\% doxycycline, $4.25 \%$ citric acid and $0.5 \%$ polysorbate $80[11,45]$. The latter is a detergent. Doxycycline and other tetracyclines are not only antibacterial, but also are calcium chelators [46]. $\mathrm{NaOCl}$ is thought to oxidize the doxycycline component of MTAD when these irrigants are mixed [47]. In benchtop experiments, the reaction of the two results in the immediate formation of a yellow-green precipitate, which develops into a purple-brown color with time and light exposure [47]. Adding the reducing agent ascorbic acid to $\mathrm{NaOCl}$ before mixing with MTAD can stop precipitate formation [47].

\subsubsection{Clinical Implications}

Because of their calcium chelation ability, tetracyclines have a high affinity for tooth structure [46], and dark brown staining can occur when root canals are irrigated sequentially by $\mathrm{NaOCl}$ and MTAD [47]. This irrigation sequence also results in a reduction of the substantivity of the MTAD antimicrobial action. Clinically, this can be avoided by neutralizing the oxidizing action of $\mathrm{NaOCl}$ with a rinse of ascorbic acid before the MTAD is applied into the root canal [47].

\subsection{Reactions of Sodium Hypochlorite with Octenisept}

\subsubsection{Chemistry}

Octenisept ${ }^{\mathrm{TM}}$ is an antimicrobial containing $0.1 \%$ octenidine and $2 \%$ phenoxyethanol [48]. Octenidine is a dicationic bispyridinamine compound [38,49] with antimicrobial activity against endodontic pathogens [50]. The cloudy white substance that forms when $\mathrm{NaOCl}$ is added to octenisept has been identified as phenoxyethanol, which precipitates out of solution upon mixing [48]. Mixtures of $\mathrm{NaOCl}$ and octenisept do not lose free available chlorine over time [9].

\subsubsection{Clinical Implications}

Recent research on the $\mathrm{NaOCl}$ /octenisept combination has highlighted that there are few clinical implications, because of the lack of interactions between these. Moreover, phenoxyethanol precipitates only minimally occlude dentinal tubules $[9,48]$. Further research into the $\mathrm{NaOCl}$ /octenisept combination is needed in order to establish if this new mixture has advantages over existing protocols.

\section{Conclusions}

The mixing of sodium hypochlorite with other endodontic irrigants can result in not only a lowering of the $\mathrm{pH}$ of the hypochlorite component and its decomposition to chlorine gas, but also in the formation of unwanted by-products originating from the added irrigant. These two processes have implications in terms of clinical performance and toxicity. Rapid loss of free available chlorine inactivates the tissue dissolution capacity of sodium hypochlorite and precipitate formation can occlude dentinal tubules. Complete chemical analysis of breakdown products remains an important objective whenever considering combining agents with sodium hypochlorite.

Acknowledgments: P.P.W. is supported by a UQ Graduate School scholarship.

Conflicts of Interest: The authors declare no conflicts of interest. 


\section{References}

1. Dakin, H.D. On the use of certain antiseptic substances in the treatment of infected wounds. Br. Med. J. 1915, 2, 318-320. [CrossRef] [PubMed]

2. Walker, A. A definite and dependable therapy for pulpless teeth. J. Am. Dent. Assoc. 1936, 23, 1418-1425.

3. Haapasalo, M.; Shen, Y.; Wang, Z.; Gao, Y. Irrigation in endodontics. Br. Dent. J. 2014, 216, $299-303$. [CrossRef] [PubMed]

4. Shen, Y.; Gao, Y.; Lin, J.; Ma, J.; Wang, Z.; Haapasalo, M. Methods and models to study irrigation. Endod. Top. 2012, 27, 3-34. [CrossRef]

5. Wayman, B.E.; Kopp, W.M.; Pinero, G.J.; Lazzari, E. Citric and lactic acids as root canal irrigants in vitro. J. Endod. 1979, 5, 258-265. [CrossRef]

6. Haapasalo, M.; Shen, Y.; Qian, W.; Gao, Y. Irrigation in endodontics. Dent. Clin. N. Am. 2010, 54, $291-312$. [CrossRef] [PubMed]

7. Zehnder, M.; Schmidlin, P.; Sener, B.; Waltimo, T. Chelation in root canal therapy reconsidered. J. Endod. 2005, 31, 817-820. [CrossRef] [PubMed]

8. Ruiz-Linares, M.; Aguado-Pérez, B.; Baca, P.; Arias-Moliz, M.; Ferrer-Luque, C. Efficacy of antimicrobial solutions against polymicrobial root canal biofilm. Int. Endod. J. 2017, 50, 77-83. [CrossRef] [PubMed]

9. Krishnan, U.; Saji, S.; Clarkson, R.; Lalloo, R.; Moule, A.J. Free active chlorine in sodium hypochlorite solutions admixed with octenidine, smearoff, chlorhexidine, and EDTA. J. Endod. 2017, 43, 1354-1359. [CrossRef] [PubMed]

10. Zehnder, M. Root canal irrigants. J. Endod. 2006, 32, 389-398. [CrossRef] [PubMed]

11. Tay, F.R.; Hiraishi, N.; Schuster, G.S.; Pashley, D.H.; Loushine, R.J.; Ounsi, H.F.; Grandini, S.; Yau, J.Y.; Mazzoni, A.; Donnelly, A.; et al. Reduction in antimicrobial substantivity of MTAD after initial sodium hypochlorite irrigation. J. Endod. 2006, 32, 970-975. [CrossRef] [PubMed]

12. Clarkson, R.; Moule, A.; Podlich, H.; Kellaway, R.; Macfarlane, R.; Lewis, D.; Rowell, J. Dissolution of porcine incisor pulps in sodium hypochlorite solutions of varying compositions and concentrations. Aust. Dent. J. 2006, 51, 245-251. [CrossRef] [PubMed]

13. Cárdenas-Bahena, Á.; Sánchez-García, S.; Tinajero-Morales, C.; González-Rodríguez, V.M.; Baires-Várguez, L. Use of sodium hypochlorite in root canal irrigation. Opinion survey and concentration in commercial products. Rev. Odontol. Mex. 2012, 16, 252-258.

14. Fukuzaki, S. Mechanisms of actions of sodium hypochlorite in cleaning and disinfection processes. Biocontrol Sci. 2006, 11, 147-157. [CrossRef] [PubMed]

15. Del Carpio-Perochena, A.; Bramante, C.M.; de Andrade, F.B.; Maliza, A.G.A.; Cavenago, B.C.; Marciano, M.A.; Amoroso-Silva, P.; Duarte, M.H. Antibacterial and dissolution ability of sodium hypochlorite in different pHs on multi-species biofilms. Clin. Oral Investig. 2015, 19, 2067-2073. [CrossRef] [PubMed]

16. Tartari, T.; Oda, D.; Zancan, R.; Silva, T.; Moraes, I.; Duarte, M.; Bramante, C. Mixture of alkaline tetrasodium EDTA with sodium hypochlorite promotes in vitro smear layer removal and organic matter dissolution during biomechanical preparation. Int. Endod. J. 2017, 50, 106-114. [CrossRef] [PubMed]

17. Arias-Moliz, M.T.; Morago, A.; Ordinola-Zapata, R.; Ferrer-Luque, C.M.; Ruiz-Linares, M.; Baca, P. Effects of dentin debris on the antimicrobial properties of sodium hypochlorite and etidronic acid. J. Endod. 2016, 42, 771-775. [CrossRef] [PubMed]

18. Vanysek, P. Electrochemical series. In CRC Handbook of Chemistry and Physics, 91st ed.; Haynes, W., Ed.; CRC Press: Boca Raton, FL, USA, 2010.

19. Nowicki, J.B.; Sem, D.S. An in vitro spectroscopic analysis to determine the chemical composition of the precipitate formed by mixing sodium hypochlorite and chlorhexidine. J. Endod. 2011, 37, 983-988. [CrossRef] [PubMed]

20. Baumgartner, J.C.; Ibay, A.C. The chemical reactions of irrigants used for root canal debridement. J. Endod. 1987, 13, 47-51. [CrossRef]

21. Clarkson, R.M.; Podlich, H.M.; Moule, A.J. Influence of ethylenediaminetetraacetic acid on the active chlorine content of sodium hypochlorite solutions when mixed in various proportions. J. Endod. 2011, 37, 538-543. [CrossRef] [PubMed]

22. Grawehr, M.; Sener, B.; Waltimo, T.; Zehnder, M. Interactions of ethylenediamine tetraacetic acid with sodium hypochlorite in aqueous solutions. Int. Endod. J. 2003, 36, 411-415. [CrossRef] [PubMed] 
23. Prado, M.; Júnior, H.M.S.; Rezende, C.M.; Pinto, A.C.; Faria, R.B.; Simão, R.A.; Gomes, B.P. Interactions between irrigants commonly used in endodontic practice: A chemical analysis. J. Endod. 2013, 39, 505-510. [CrossRef] [PubMed]

24. Grande, N.M.; Plotino, G.; Falanga, A.; Pomponi, M.; Somma, F. Interaction between EDTA and sodium hypochlorite: A nuclear magnetic resonance analysis. J. Endod. 2006, 32, 460-464. [CrossRef] [PubMed]

25. Biel, P.; Mohn, D.; Attin, T.; Zehnder, M. Interactions between the tetrasodium salts of EDTA and 1-hydroxyethane 1, 1-diphosphonic acid with sodium hypochlorite irrigants. J. Endod. 2017, 43, 657-661. [CrossRef] [PubMed]

26. De Almeida, L.H.S.; Gomes, A.P.N.; Souza, E.M.; Pappen, F.G. Influence of EDTA and dentine in tissue dissolution ability of sodium hypochlorite. Aust. Endod. J. 2015, 41, 7-11. [CrossRef] [PubMed]

27. Tokuda, M.; Kawakami, Y.; Morimoto-Yamashita, Y.; Torii, M. Subcutaneous emphysema caused by sodium hypochlorite plus RC-prep. Open J. Stom. 2014, 4, 527. [CrossRef]

28. Guerreiro-Tanomaru, J.M.; Morgental, R.D.; Flumignan, D.L.; Gasparini, F.; Oliveira, J.E.; Tanomaru-Filho, M. Evaluation of $\mathrm{pH}$, available chlorine content, and antibacterial activity of endodontic irrigants and their combinations against Enterococcus faecalis. Oral Surg. Oral Med. Oral Pathol. Oral Radiol. Endod. 2011, 112, 132-135. [CrossRef] [PubMed]

29. Tartari, T.; Guimaraes, B.M.; Amoras, L.S.; Duarte, M.A.; Silva e Souza, P.A.; Bramante, C.M. Etidronate causes minimal changes in the ability of sodium hypochlorite to dissolve organic matter. Int. Endod. J. 2015, 48, 399-404. [CrossRef] [PubMed]

30. Lottanti, S.; Gautschi, H.; Sener, B.; Zehnder, M. Effects of ethylenediaminetetraacetic, etidronic and peracetic acid irrigation on human root dentine and the smear layer. Int. Endod. J. 2009, 42, 335-343. [CrossRef] [PubMed]

31. Arias-Moliz, M.T.; Ordinola-Zapata, R.; Baca, P.; Ruiz-Linares, M.; Ferrer-Luque, C.M. Antimicrobial activity of a sodium hypochlorite/etidronic acid irrigant solution. J. Endod. 2014, 40, 1999-2002. [CrossRef] [PubMed]

32. Russell, A.; Day, M. Antibacterial activity of chlorhexidine. J. Hosp. Infect. 1993, 25, 229-238. [CrossRef]

33. Tanzer, J.; Slee, A.; Kamay, B. Structural requirements of guanide, biguanide, and bisbiguanide agents for antiplaque activity. Antimicrob. Agents Chemother. 1977, 12, 721-729. [CrossRef] [PubMed]

34. Basrani, B.R.; Manek, S.; Sodhi, R.N.; Fillery, E.; Manzur, A. Interaction between sodium hypochlorite and chlorhexidine gluconate. J. Endod. 2007, 33, 966-969. [CrossRef] [PubMed]

35. Krishnamurthy, S.; Sudhakaran, S. Evaluation and prevention of the precipitate formed on interaction between sodium hypochlorite and chlorhexidine. J. Endod. 2010, 36, 1154-1157. [CrossRef] [PubMed]

36. Kolosowski, K.P.; Sodhi, R.N.; Kishen, A.; Basrani, B.R. Qualitative analysis of precipitate formation on the surface and in the tubules of dentin irrigated with sodium hypochlorite and a final rinse of chlorhexidine or QMiX. J. Endod. 2014, 40, 2036-2040. [CrossRef] [PubMed]

37. Mortenson, D.; Sadilek, M.; Flake, N.M.; Paranjpe, A.; Heling, I.; Johnson, J.D.; Cohenca, N. The effect of using an alternative irrigant between sodium hypochlorite and chlorhexidine to prevent the formation of para-chloroaniline within the root canal system. Int. Endod. J. 2012, 45, 878-882. [CrossRef] [PubMed]

38. Thomas, J.E.; Sem, D.S. An in vitro spectroscopic analysis to determine whether para-chloroaniline is produced from mixing sodium hypochlorite and chlorhexidine. J. Endod. 2010, 36, 315-317. [CrossRef] [PubMed]

39. Orhan, E.O.; Irmak, Ö.; Hür, D.; Yaman, B.C.; Karabucak, B. Does para-chloroaniline really form after mixing sodium hypochlorite and chlorhexidine? J. Endod. 2016, 42, 455-459. [CrossRef] [PubMed]

40. Basrani, B.; Santos, J.M.; Tjäderhane, L.; Grad, H.; Gorduysus, O.; Huang, J.; Lawrence, H.P.; Friedman, S. Substantive antimicrobial activity in chlorhexidine-treated human root dentin. Oral Surg. Oral Med. Oral Pathol. Oral Radiol. Endod. 2002, 94, 240-245. [CrossRef] [PubMed]

41. Bui, T.B.; Baumgartner, J.C.; Mitchell, J.C. Evaluation of the interaction between sodium hypochlorite and chlorhexidine gluconate and its effect on root dentin. J. Endod. 2008, 34, 181-185. [CrossRef] [PubMed]

42. Gasic, J.; Popovic, J.; Živković, S.; Petrovic, A.; Barac, R.; Nikolic, M. Ultrastructural analysis of the root canal walls after simultaneous irrigation of different sodium hypochlorite concentration and $0.2 \%$ chlorhexidine gluconate. Microsc. Res. Tech. 2012, 75, 1099-1103. [CrossRef] [PubMed]

43. Akisue, E.; Tomita, V.S.; Gavini, G.; de Figueiredo, J.A.P. Effect of the combination of sodium hypochlorite and chlorhexidine on dentinal permeability and scanning electron microscopy precipitate observation. J. Endod. 2010, 36, 847-850. [CrossRef] [PubMed] 
44. Kim, H.S.; Zhu, Q.; Baek, S.H.; Jung, I.Y.; Son, W.J.; Chang, S.W.; Lee, W.; Gu, Y.; Lee, Y.; Hong, S.T.; et al. Chemical interaction of alexidine and sodium hypochlorite. J. Endod. 2012, 38, 112-116. [CrossRef] [PubMed]

45. Tong, Z.; Ling, J.; Lin, Z.; Li, X.; Mu, Y. The effect of MTADN on 10 Enterococcus faecalis isolates and biofilm: An in vitro study. J. Endod. 2013, 39, 674-678. [CrossRef] [PubMed]

46. Caswell, A.; Hutchison, J. Selectivity of cation chelation to tetracyclines: Evidence for special conformation of calcium chelate. Biochem. Biophys. Res. Commun. 1971, 43, 625-630. [CrossRef]

47. Tay, F.R.; Mazzoni, A.; Pashley, D.H.; Day, T.E.; Ngoh, E.C.; Breschi, L. Potential iatrogenic tetracycline staining of endodontically treated teeth via $\mathrm{NaOCl} / \mathrm{MTAD}$ irrigation: A preliminary report. J. Endod. 2006, 32, 354-358. [CrossRef] [PubMed]

48. Thaha, K.A.; Varma, R.L.; Nair, M.G.; Joseph, V.S.; Krishnan, U. Interaction between octenidine-based solution and sodium hypochlorite: A mass spectroscopy, proton nuclear magnetic resonance, and scanning electron microscopy-based observational study. J. Endod. 2017, 43, 135-140. [CrossRef] [PubMed]

49. Bailey, D.M.; DeGrazia, C.G.; Hoff, S.J.; Schulenberg, P.L.; O'Connor, J.R.; Paris, D.A.; Slee, A.M. Bispyridinamines: A new class of topical antimicrobial agents as inhibitors of dental plaque. J. Med. Chem. 1984, 27, 1457-1464. [CrossRef] [PubMed]

50. Tirali, R.E.; Turan, Y.; Akal, N.; Karahan, Z.C. In vitro antimicrobial activity of several concentrations of $\mathrm{NaOCl}$ and Octenisept in elimination of endodontic pathogens. Oral Surg. Oral Med. Oral Pathol. Oral Radiol. Endod. 2009, 108, e117-e120. [CrossRef] [PubMed]

(C) 2017 by the authors. Licensee MDPI, Basel, Switzerland. This article is an open access article distributed under the terms and conditions of the Creative Commons Attribution (CC BY) license (http:/ / creativecommons.org/licenses/by/4.0/). 